\title{
The 2012-2016 eruptive cycle at Copahue volcano (Argentina) versus the peripheral gas manifestations: hints from the chemical and isotopic features of fumarolic fluids
}

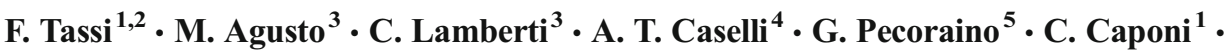 \\ J. Szentiványi ${ }^{3} \cdot$ S. Venturi ${ }^{1,2} \cdot$ O. Vaselli ${ }^{1,2}$
}

Received: 3 March 2017 / Accepted: 22 August 2017 /Published online: 12 September 2017

(C) Springer-Verlag GmbH Germany 2017

\begin{abstract}
This study presents the chemical and isotopic compositions of hydrothermal gases from fumaroles discharging around Copahue volcano (Argentina). Gas samples, including those from two fumaroles at the active summit crater, were collected during 13 surveys carried out by different research teams from 1976 to February 2016. The time-series of $\mathrm{H}_{2}$, $\mathrm{CO}$ and light hydrocarbons showed episodic increases related to the main events of the last eruptive cycle that started on 19 July 2012. Concentration peaks were likely caused by enhanced input of hot magmatic fluids affecting the hydrothermal reservoir. These data contrast with the temporal variations shown by $R c / R a$ and $\delta^{13} \mathrm{C}_{-} \mathrm{CO}_{2}$ values in $2012-2014$, which indicated an increasing input from a crustal fluid source. In 2015-2016, however, these isotopic parameters showed opposite trends; their composition became closer to that of the two summit fumaroles, which possibly corresponds to that of the deep magmatic-related end-member. The delayed and reduced compositional changes in the peripheral hydrothermal fluid
\end{abstract}

Editorial responsibility: T.P. Fischer

F. Tassi

franco.tassi@unifi.it

1 Department of Earth Sciences, University of Florence, Via La Pira, 4, 50121 Florence, Italy

2 Institute of Geosciences and Earth Resources of the National Research Council (CNR-IGG), Via La Pira, 4, 50121 Florence, Italy

3 GESVA-IDEAN, Dpto. Cs. Geológicas, FCEN, Universidad de Buenos Aires, Ciudad Universitaria, Pab.2, 1428 Buenos Aires, Argentina

4 LESVA, Universidad Nacional de Río Negro, Roca 1242, 8332 General Roca, Argentina

5 Istituto Nazionale di Geofisica e Vulcanologia, Via U. La Malfa 153, 90146 Palermo, Italy discharge in response to the 2012-2016 eruptive events suggest that geochemical surveys of these emissions are unlikely to provide premonitory signals of volcanic unrest if the volcanic activity remains centered in the main crater. Instead, an instrument which is able to provide measurements of volcanic gases in the air (e.g. MultiGAS) may be used to detect changes at the summit crater. Otherwise, monitoring of seismic activity and ground deformation, as well as the periodic measurement of the chemistry of the water in the Rio Agrio, which is fed by thermal discharge from the summit crater, seem to represent the most reliable means of monitoring at Copahue. However, the relative compositional stability of the hydrothermal reservoir is a great advantage in terms of geothermal resource exploitation and could encourage new investments in the Copahue geothermal project which was abandoned in the 1990s.

Keywords Geochemical monitoring · Copahue volcano · Fluid geochemistry $\cdot$ Hydrothermal system $\cdot$ Active volcano

\section{Introduction}

Fumarolic gases discharging from hydrothermal reservoirs hosted in quiescent volcanoes carry sensitive compounds (e.g. $\mathrm{H}_{2}, \mathrm{CO}, \mathrm{CO}_{2}, \mathrm{CH}_{4}$ and $\mathrm{H}_{2} \mathrm{O}$ ) that provide the means for investigating the chemical-physical conditions of the deep environment (e.g. Giggenbach 1987, 1996; Chiodini and Marini 1998). Noble gas isotopic signatures are useful tracers for identifying fluid source regions, especially in subduction zones (e.g. Poreda and Craig 1989; Giggenbach et al. 1993; Fischer et al. 2002; Hilton et al. 2002, 2010; Shaw et al. 2003; Sano and Fischer 2013). Accordingly, fluid discharge is periodically monitored to assess the degassing behavior of magmatic bodies (e.g. Menyailov et al. 1986; Tassi et al. 2016) and changes in volcanic activity (e.g. Chiodini et al. 
1995; Fischer et al. 1996, 2015; Symonds et al. 1996; Vaselli et al. 2010; Melián et al. 2012). On the other hand, innovative remote sensing techniques, able to continuously acquire chemical data of gases, provide valuable insights into the behavior of active volcanoes and eruption forecasting (e.g. Aiuppa et al. 2009). Although the monitoring of magmatichydrothermal fluids has for many decades been considered a robust prognostic tool for detecting rejuvenation of volcanic activity (e.g. Stoibert and Rose 1970), it is not surprising that long-term geochemical time-series datasets are available for only a relatively small number of volcanic systems. This is particularly true for volcanoes located in developing countries, where logistic and economic problems often hinder the development of long-term research projects, which are frequently operated and funded by western countries.

The geochemistry of fluids discharged from geothermal wells and natural emissions located in the surroundings of the main cone of Copahue volcano (Argentina) has been investigated since the 1970 s within the framework of geothermal exploration projects carried out by private companies (Mas and Mas 2016 and references therein). Geochemical studies were performed on this system from 2006 to 2012, with the aim of constructing a comprehensive conceptual geochemical model describing the primary fluid sources and the secondary processes controlling the chemistry of the fluid discharge (Agusto et al. 2013; Tassi et al. 2016). A new eruptive cycle, which began on 19 July 2012 (after 12 years of quiescence), was characterized by occasional phreatic and phreatomagmatic eruptions (Caselli et al. 2016a); it promoted further surveys, providing the opportunity to upgrade and improve the geochemical database of fluids emitted from this volcano.

In this paper, we present both new and previously published chemical and isotopic $\left({ }^{3} \mathrm{He} /{ }^{4} \mathrm{He}\right.$ and $\delta^{13} \mathrm{C}$ in $\left.\mathrm{CO}_{2}\right)$ data for gases from the main fluid discharge sources of Copahue volcano. This unique geochemical dataset covers, albeit discontinuously, a 40-year observation period (from 1976 to 2016) and is used to describe the relationships between the ongoing volcanic activity and the temporal evolution of the hydrothermal reservoir feeding the surficial emissions. In addition, the chemistry of two fumaroles sampled in March 2013, which are currently to the best of our knowledge the only available gas samples from the volcano's summit crater, is also reported.

\section{Geological and volcanological settings}

Volcanism in the Southern Andean Volcanic Zone (SAVZ) is related to the subduction of the Nazca Plate beneath the South American Plate (Pesicek et al. 2012 and references therein). Copahue volcano belongs to the Caviahue-Copahue Volcanic Complex (CCVC, $38^{\circ} \mathrm{S}-71^{\circ} \mathrm{W}$; Argentina-Chile) that is located at the transition between the southern strike-slip Liquiñe-Ofqui and the northern compressive CopahueAntiñir Fault systems (Fig. 1a) (Cembrano et al. 1996, 2002; Stern 2004; Radic 2010). Early Pliocene basaltic-andesitic eruptions associated with extensional and/or transtensional processes ended in the latest Pliocene-early Pleistocene, with the formation of a series of calderas which discharged large amounts of ignimbrite (Folguera et al. 2016). The construction of the CCVC volcanic edifice, which has an elongated NESW shape and lies on basement consisting of volcanic sequences belonging to the Cola de Zorro Formation, began $\sim 1.23 \mathrm{Ma}$ in the western sector of one of the Caviahue Caldera. This relatively young stratovolcano was intruded by the 1 Ma dacitic Pucón Mahuida dome, whose volcanic products were covered by pre-glacial lavas, ignimbrites and tuffs (1-0.7 Ma; Copahue Stage 1) and syn- and post-glacial pillow lavas (700-15 ka; Copahue Stage 2). Volcanic products of Copahue Stage $3(<\sim 15 \mathrm{ka})$ consist of lavas erupted from post-glacial vents located along the northern slope and the highest, most easterly crater of the stratocone (Melnick et al. 2006).

The 200 m-wide easternmost crater of the Copahue summit, which has nine $\mathrm{N} 60^{\circ} \mathrm{E}$-aligned craters, has experienced 13 phreatic and low-magnitude phreatomagmatic eruptive episodes over the last 260 years in 1750, 1759, 1867, 1937, 1944, 1960, 1961, 1992, 1993, 1994, 1995, 2000 and 2012present (Caselli et al. 2016b and references therein).

\section{The 2012-2016 eruptive cycle}

Precursory signals for the 2012-2016 eruptive cycle mainly consisted of enhanced high- and low-frequency seismic activities, which followed the Mw 8.8 Maule earthquake (February 27, 2010) (Forte et al. 2012). At the end of 2011, a 200-300 m-high column of dense vapor was produced by the summit crater, followed by a progressive increase in seismic signals (INPRES, Araujo, personal communication). Significant changes in temperature, $\mathrm{pH}$ and chemical composition of the hyperacidic lake located within the summit crater were also recorded. On 17 July 2012, a small-scale phreatic explosion from the crater lake was observed, followed two days later by phreatomagmatic eruptions that produced a small E-SE-oriented plume of about $18 \mathrm{~km}$ in length (Caselli et al. 2016a). In August-November 2012, the fumarolic activity in the summit crater was persistently intense, causing a decrease in the lake water level of $\sim 20 \mathrm{~m}$. On 22 December 2012 at 12:05 (GMT), an 800 m-high white vapor column was emitted from the active crater that, in a few hours, caused the complete evaporation of the crater lake. Ash columns and incandescent material which was distributed over an area of $\sim 8700 \mathrm{~km}^{2}$ to the SE were produced during the following phreatomagmatic and strombolian eruptions 


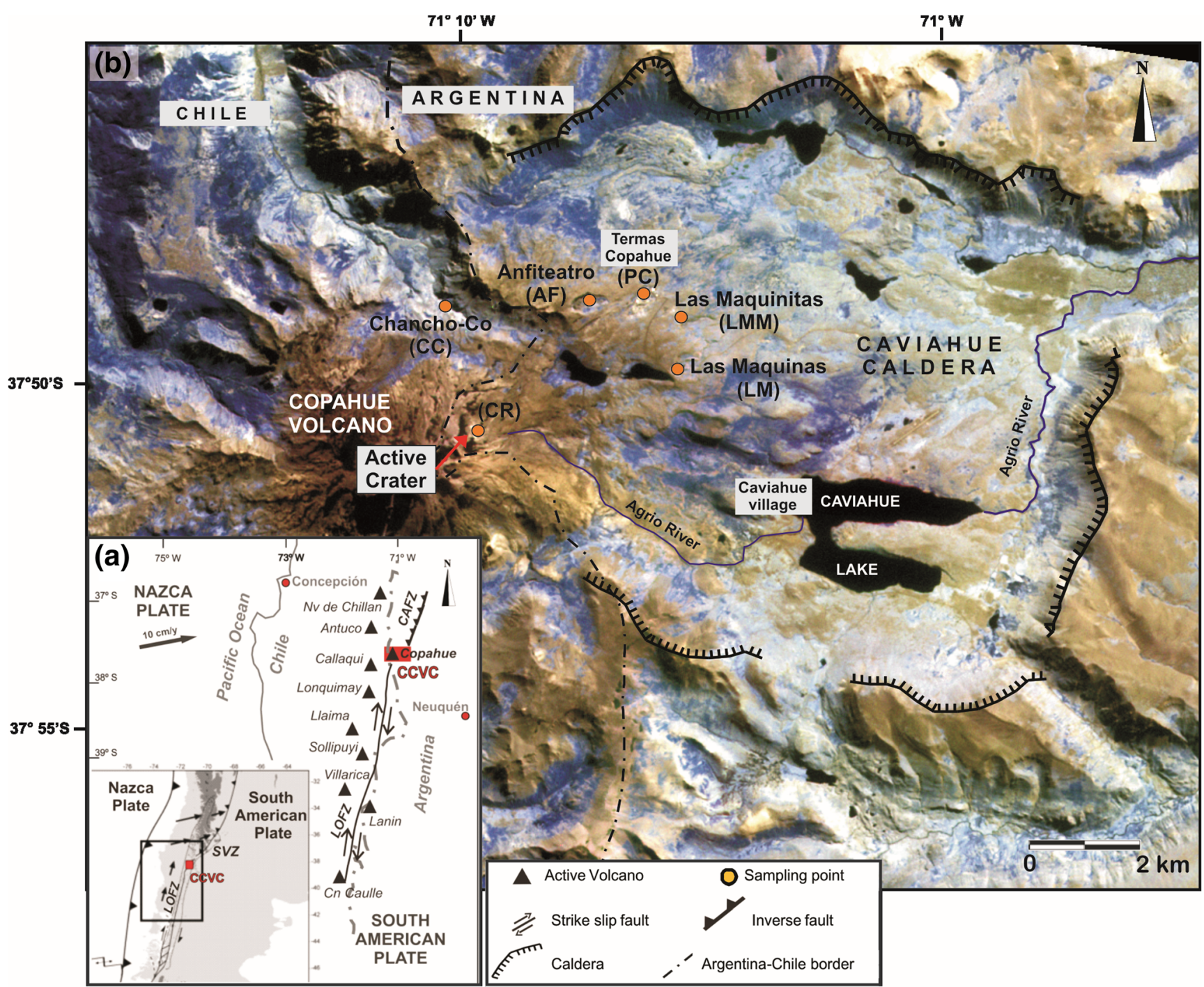

Fig. 1 (a) Schematic map of the northern transitional and central segments of the Southern Andean Volcanic Zone with location of the main active volcanoes and Caviahue-Copahue Volcanic Complex

(Petrinovic et al. 2014; Caselli et al. 2016a). In 2013, no significant volcanic events were observed. This pause allowed, by the end of 2013, the refilling of the crater lake, although its volume was significantly smaller than that recorded before the summer of 2012. This period of quiescence lasted until July 2014, when a phreatic explosion generated lahars on the eastern flank of the volcanic edifice. In early October 2014, the lake once again dried out due to the occurrence of a phreatomagmatic eruption with the emission of ash and volcanic bombs, containing sulfur particles and quenched liquid sulfur, respectively (Caselli et al. 2016a and references therein). In January-February 2015, the presence of a new crater lake was observed. In October 2015, a strong phreatomagmatic to magmatic eruption occurred. After this event, a small new crater lake, which was still present during the sampling fieldtrip carried out in February 2016, formed again.
(CCVC); (b) map of CCVC area with location of the gas sampling sites (modified from Agusto et al. 2013)

\section{Conceptual model of the Copahue hydrothermal-magmatic system}

Varekamp et al. (2004, 2006) suggested that a magmadominated brine was feeding the crater lake, the latter receiving fluids from a magma batch at $\sim 4-5 \mathrm{~km}$ depth (Velez et al. 2011). The strong relationship between (a) the lake's geochemical features and volume and (b) the rate of magmatic gas inputs was recently confirmed by Agusto and Varekamp (2016), who based their assessment on 15 years (1997-2012) of periodical observations. The release of magmatic fluids from the Copahue crater even during periods of quiescence was confirmed in March 2013 by both the analysis of two crater fumaroles, included in the present paper, and a variety of in situ and remote sensing measurements carried out in March 2014, which identified a plume released from the crater lake which was discharging up to $\sim 1400 \mathrm{t} /$ day of $\mathrm{SO}_{2}$ (Tamburello et al. 2015). 
There are five distinct areas around the volcanic edifice, where thermal fluid emissions, consisting of fumaroles and boiling-bubbling water and mud pools occur: Las Máquinas (LM), Las Maquinitas (LMM), Termas de Copahue (PC), Anfiteatro (AF) and Chancho Co (CC) (Fig. 1b). The origin of the fluids discharged from these peripheral emissions was firstly investigated within the framework of geological, geochemical and geophysical surveys carried out since 1974 for a preliminary evaluation of the area's geothermal potential (Jurío 1977; Panarello et al. 1988; Panarello 2002; JICA 1992). The chemical and physical characteristics of fluids from four wells drilled at different times (1976, 1981 and 1998) $\sim 5 \mathrm{~km} \mathrm{NW}$ of the volcano summit (Mas and Mas 2016 and references therein) indicated the occurrence of two main hydrothermal aquifers located at $800-1000$ and $>1400 \mathrm{~m}$ depth. The latter had a temperature of up to $250{ }^{\circ} \mathrm{C}$, as also confirmed by geothermometric estimations in the $\mathrm{H}_{2} \mathrm{O}-\mathrm{CO}_{2}-\mathrm{CH}_{4}-\mathrm{C}_{3} \mathrm{H}_{6}-\mathrm{C}_{3} \mathrm{H}_{8}$ system (Tassi et al. 2016). This multi-layer peripheral reservoir was found to have been produced by the interaction between magmatic gases and meteoric water (Agusto et al. 2013). This process is responsible for (a) the dissolution of strongly acidic gases from magma degassing $\left(\mathrm{SO}_{2}, \mathrm{HCl}\right.$ and $\left.\mathrm{HF}\right)$ and (b) the production of the typical hydrothermal gases, i.e. $\mathrm{H}_{2}, \mathrm{H}_{2} \mathrm{~S}$, $\mathrm{CO}, \mathrm{CH}_{4}$ and light hydrocarbons.

\section{Gas sampling and analytical methods}

Gas samples were collected from selected fumaroles (LM, LMM, PC, AF and CC) in the five main hydrothermal areas (Fig. 1b). No fumarolic emissions had been seen at the summit crater over the last few decades, due to the presence of the crater's lake. However, in March 2013, the lake almost completely dried out due to the high discharge rate of magmatic fluids, allowing access to the crater bottom, where two fumaroles (CR1 and CR2) were sampled (Tamburello et al. 2015).

The sampling and analytical procedures adopted for the gases constituting the new dataset (from December 2012 to March 2016) were similar to those used to produce most of the previous data (from November 2006 to March 2012; Agusto et al. 2013). The gas sampling line consisted of a $1 \mathrm{~m}$-long titanium tube $(\varnothing=2.5 \mathrm{~cm})$ and Pyrex glass-dewared pipes connected to pre-weighted and pre-evacuated $50-\mathrm{mL}$ glass Thorion®-tapped flasks filled with $20 \mathrm{~mL}$ of a $4 \mathrm{~N} \mathrm{NaOH}$ and $0.15 \mathrm{M} \mathrm{Cd}(\mathrm{OH})_{2}$ suspension (Montegrossi et al. 2001). This technique allows $\mathrm{SO}_{2}$ to be separated in situ and then dissolved in the alkaline solution with water vapor and acidic gases $\left(\mathrm{CO}_{2}, \mathrm{HCl}, \mathrm{HF}\right)$. The $\mathrm{H}_{2} \mathrm{~S}$ forms insoluble $\mathrm{CdS}$, whereas low-solubility gas species $\mathrm{N}_{2}, \mathrm{O}_{2}, \mathrm{CO}, \mathrm{H}_{2}, \mathrm{He}, \mathrm{Ar}, \mathrm{CH}_{4}$ and light hydrocarbons) are trapped in the flask headspace. Steam condensates (for the analysis of the $\delta^{18} \mathrm{O}$ and $\delta \mathrm{D}$ ratios in water vapor) and dry gases (for the analysis of the ${ }^{13} \mathrm{C} /{ }^{12} \mathrm{C}$ ratios in $\mathrm{CO}_{2}$ and $\mathrm{He}$ isotopes) were collected using a watercooled condenser connected to the soda flask sampling line.

Inorganic $\left(\mathrm{N}_{2}, \mathrm{Ar}, \mathrm{O}_{2}, \mathrm{H}_{2}, \mathrm{He}\right.$ and $\left.\mathrm{CO}\right)$ and organic $\left(\mathrm{C}_{1}-\mathrm{C}_{3}\right.$ hydrocarbons) gases from the flask headspace were analyzed at the Laboratory of Fluid Geochemistry of the University of Florence (Italy) by gas chromatography (GC Shimadzu 15A, Shimadzu 14 and Thermo Focus). The liquid and the solid phases of the suspension were separated by centrifuge, to analyze for $\mathrm{CO}_{2}, \mathrm{SO}_{2}, \mathrm{HCl}$ and $\mathrm{HF}$, in the form of $\mathrm{CO}_{3}{ }^{2-}$ (by acidimetric titration, AT; Metrohm Basic Titrino), $\mathrm{SO}_{4}{ }^{2-}, \mathrm{Cl}^{-}$and $\mathrm{F}^{-}$(by ion chromatography, IC; Metrohm 761), respectively. The CdS precipitate was dissolved by oxidation with $\mathrm{H}_{2} \mathrm{O}_{2}$ in order to analyze $\mathrm{H}_{2} \mathrm{~S}$ as $\mathrm{SO}_{4}{ }^{2-}$ by IC. The analytical error for GC, AT and IC analyses was $<5 \%$.

The analysis of ${ }^{13} \mathrm{C} /{ }^{12} \mathrm{C}$ of $\mathrm{CO}_{2}$ (expressed as $\delta^{13} \mathrm{C}^{-} \mathrm{CO}_{2} \%$ o vs. V-PDB) was carried out at the CNR-IGG laboratory of Stable Isotopes (Pisa, Italy) using a Finnigan MAT252 mass spectrometer after standard extraction and purification procedures of the gas mixtures (Evans et al. 1998) performed at the Department of Earth Sciences of Florence (Italy). Carrara and San Vincenzo marbles, as well as international NBS18 and NBS19 standards, were used to estimate the external precision. The analytical error and the reproducibility were \pm 0.05 and $\pm 0.1 \%$, respectively.

The $R / R a$ (where $R$ is the ${ }^{3} \mathrm{He} /{ }^{4} \mathrm{He}$ measured ratio and $R a$ is the ${ }^{3} \mathrm{He} /{ }^{4} \mathrm{He}$ ratio in the air $1.39 \times 10^{-6}$; Mamyrin and Tolstikhin 1984) and ${ }^{4} \mathrm{He} /{ }^{20} \mathrm{Ne}$ ratios were determined at the INGV laboratories in Palermo (Italy) by separately introducing $\mathrm{He}$ and $\mathrm{Ne}$ into a split-flighttube mass spectrometer (GVI Helix SFT) after performing standard purification procedures (e.g. Rizzo et al. 2015). The analytical error was $\pm 1 \%$. The measured $R / R a$ values were corrected for air contamination using the ${ }^{4} \mathrm{He} /{ }^{20} \mathrm{Ne}$ ratios (Poreda and Craig 1989), as follows:

$R c / R a=[(R / R a)-r)] /(1-r)$

where $r=\left({ }^{4} \mathrm{He} /{ }^{20} \mathrm{Ne}\right)_{\text {air }} /\left({ }^{4} \mathrm{He} /{ }^{20} \mathrm{Ne}\right)_{\text {meas }}$, the $\left({ }^{4} \mathrm{He} /{ }^{20} \mathrm{Ne}\right)_{\text {air }}$ ratio being that in the atmosphere $(0.318$; Ozima and Posodek $1983)$ and the $\left({ }^{4} \mathrm{He} /{ }^{20} \mathrm{Ne}\right)_{\text {meas }}$ ratio that measured in the gas sample.

The ${ }^{18} \mathrm{O} /{ }^{16} \mathrm{O}$ and ${ }^{2} \mathrm{H} /{ }^{1} \mathrm{H}$ ratios of water vapor (expressed as $\delta^{18} \mathrm{O}-\mathrm{H}_{2} \mathrm{O}$ and $\delta \mathrm{D}-\mathrm{H}_{2} \mathrm{O} \%$ ovs. V-SMOW, respectively) were analyzed at the Department of Physics and Earth Sciences of the University of Parma (Italy) using a Thermo-Finnigan HDO equilibrator coupled to a Thermo-Finnigan Delta Plus mass spectrometer with double entry system. The analytical errors were \pm 0.05 and $\pm 1 \%$ or for $\delta^{18} \mathrm{O}-\mathrm{H}_{2} \mathrm{O}$ and $\delta \mathrm{D}-\mathrm{H}_{2} \mathrm{O}$, respectively. 


\section{Results}

\section{Chemical composition}

Outlet temperatures, chemical composition (dry fraction) and steam concentrations (in $\mathrm{mmol} / \mathrm{mol}$ for the main species, in $\mu \mathrm{mol} / \mathrm{mol}$ for all hydrocarbons except $\mathrm{CH}_{4}$ ) of the fumarolic gases collected from December 2012 to March 2016 are reported in Table 1. Data from the literature for gases collected from the emissions in 1976 (Jurío 1977), 1986 (Panarello 2002), 1997 (Martini et al. 1997), November 2006March 2012 (Agusto et al. 2013) and January 2014 (Tardani et al. 2016) are also listed in Table 1.

The LM, PC, AF and CC fumaroles were characterized by outlet temperatures $\leq 97{ }^{\circ} \mathrm{C}$, whereas those of LMM ranged from $130{ }^{\circ} \mathrm{C}$ (in 1986) to $160^{\circ} \mathrm{C}$ (in March 2012). The CR1 and CR2 outlet temperatures were 431 and $102{ }^{\circ} \mathrm{C}$, respectively. The chemical composition of the five distal discharges was typical of hydrothermal fluids (e.g. Giggenbach 1987; Chiodini and Marini 1998), mainly consisting of water vapor ( $\geq 960 \mathrm{mmol} / \mathrm{mol}$ ) with a dry gas fraction dominated by $\mathrm{CO}_{2}$ (up to $974 \mathrm{mmol} / \mathrm{mol}$ ) and variable concentrations of $\mathrm{H}_{2} \mathrm{~S}(2.5$ to $155 \mathrm{mmol} / \mathrm{mol}$ ), $\mathrm{N}_{2}$ (3 to $169 \mathrm{mmol} / \mathrm{mol}$ ), $\mathrm{H}_{2}$ (1 to $105 \mathrm{mmol} / \mathrm{mol})$ and $\mathrm{CH}_{4}(0.68$ to $55 \mathrm{mmol} / \mathrm{mol})$. He, Ar and $\mathrm{CO}$ were present in minor amounts (up to $0.089,0.31$ and $0.018 \mathrm{mmol} / \mathrm{mol}$, respectively). The $\mathrm{C}_{2}-\mathrm{C}_{3}$ hydrocarbons, whose total content was up to $52 \mu \mathrm{mol} / \mathrm{mol}$, mostly consisted of ethane $\left(\mathrm{C}_{2} \mathrm{H}_{6}\right.$, up to $\left.47 \mu \mathrm{mol} / \mathrm{mol}\right)$ and propane $\left(\mathrm{C}_{3} \mathrm{H}_{8}\right.$, up to $5.1 \mu \mathrm{mol} / \mathrm{mol}$ ), with minor concentrations of propene $\left(\mathrm{C}_{3} \mathrm{H}_{6}\right.$, up to $\left.0.0081 \mu \mathrm{mol} / \mathrm{mol}\right)$.

The chemical features of the CR1 and CR2 fumaroles were very different compared to those of the hydrothermal-type emissions, since the former were characterized by (a) significant concentrations of magmatic-related acidic gases, such as $\mathrm{SO}_{2}$ (165 and $120 \mathrm{mmol} / \mathrm{mol}$, respectively), $\mathrm{HCl}$ (5.1 and $3.8 \mathrm{mmol} / \mathrm{mol}$, respectively) and $\mathrm{HF}$ ( 2.9 and $2.6 \mathrm{mmol} / \mathrm{mol}$, respectively); (b) relatively low concentration of $\mathrm{CH}_{4}, \mathrm{C}_{2} \mathrm{H}_{6}$ and $\mathrm{C}_{3} \mathrm{H}_{8}(<0.5 \mathrm{mmol} / \mathrm{mol}$ and $\leq 0.66$ and $\leq 0.012 \mu \mathrm{mol} / \mathrm{mol}$, respectively) and (c) presence of ethene $\left(\mathrm{C}_{2} \mathrm{H}_{4} ; 0.13\right.$ and $0.11 \mu \mathrm{mol} / \mathrm{mol}$, respectively).

\section{$\delta^{13} \mathrm{C}-\mathrm{CO}_{2}$ and $\mathrm{Rc} / \mathrm{R} a$ values}

The $\delta^{13} \mathrm{C}-\mathrm{CO}_{2}, R c / R a,{ }^{4} \mathrm{He} /{ }^{20} \mathrm{Ne}, \delta^{18} \mathrm{O}-\mathrm{H}_{2} \mathrm{O}$ and $\delta \mathrm{D}-\mathrm{H}_{2} \mathrm{O}$ values of the fumarolic gases collected from December 2012 to March 2016 are reported in Table 2. In addition to the literature data from the authors cited above, isotopic data for one gas sample collected in 2003 (Varekamp et al. 2006) are also included.

The $\delta^{13} \mathrm{C}-\mathrm{CO}_{2}$ values ranged from -9.6 to $-6.7 \%$ vs. $\mathrm{V}$-PDB, with no significant differences between the different gas emissions. On the contrary, the $R c / R a$ values of the LM, LMM, PC and CR1 gases were higher (5.89 to 7.96 ) with respect to those of the $\mathrm{AF}$ and $\mathrm{CC}$ gases (4.04 to 5.35). The high ${ }^{4} \mathrm{He} /{ }^{20} \mathrm{Ne}$ ratios (23 to 2445) indicate that the effect of air contamination on the $R c / R a$ values was negligible. The $\delta^{13} \mathrm{C}$ $\mathrm{CO}_{2}$ value of the CR1 fumarole ( $-9.6 \%$ vs. V-PDB) was at the lowest limit of the range shown by the hydrothermal discharges ( -6.9 to $9.6 \%$ vs. V-PDB), whereas its $R c / R a$ value (7.75) was one of the highest measured at Copahue volcano.

The values of $\delta^{18} \mathrm{O}-\mathrm{H}_{2} \mathrm{O}$ and $\delta \mathrm{D}-\mathrm{H}_{2} \mathrm{O}$ in the condensate samples of LM, LMM, CC, AF and PC ranged from -11.8 to $-8.2 \%$ and from -92 to $-75 \%$ vs. V-SMOW, respectively, with the only exception being the AF gas sample collected in March 2012 that had more negative values ( -17.9 and $-109 \%$ vs. V-SMOW, respectively). On the contrary, the CR1 and CR2 fumaroles showed less negative values $(-3.5$ and $-66 \%$ and -3.6 and $-70 \%$ vs. V-SMOW, respectively).

\section{Discussion}

\section{Temporal evolution of the chemical composition of the gas}

Hydrothermal systems typically occur around active volcanoes, since they are produced by the interaction of hot fluids released from the magmatic bodies and shallow aquifers. This process implies that the most reactive magmatic volatiles $\left(\mathrm{SO}_{2}, \mathrm{HCl}\right.$ and $\left.\mathrm{HF}\right)$ dissolve when entering the liquid reservoir. Thus, they are commonly not identified in the hydrothermal fluid discharges. However, increasing inputs of heat and magmatic gases are expected to cause a strong perturbation in the hydrothermal-magmatic system, allowing the most soluble species, although partially scrubbed, to be released from the fumarolic discharge. Accordingly, geochemical monitoring of fumarolic fluids, including those from peripheral hydrothermal-type emissions, may record precursory signals related to physical-chemical changes occurring at depth prior to a new phase of volcanic activity. This was the case at Turrialba volcano (Costa Rica), where $\mathrm{SO}_{2}$ was firstly detected in low temperature fumaroles of the summit craters in September 2001, after three consecutive years of observations. This event was interpreted as being precursory to a volcanic crisis (Tassi et al. 2004), which actually happened almost 10 years later (Vaselli et al. 2010) and is still ongoing (de Moor et al. 2016a). Similarly, in the four months following the impressive gas burst that occurred on 3 November 2002 (Capaccioni et al. 2005), the submerged fumaroles located next to Panarea Island, a dormant volcano in the Aeolian Archipelago (southern Italy), discharged $\mathrm{SO}_{2}$-bearing gases that had never previously been detected in these fumaroles (Capaccioni et al. 2007 and references therein), revealing the temporary consumption of the liquid-dominated aquifer feeding the submarine fumarolic field likely due to a magmatic gas pulse from depth. On the other hand, experimental 


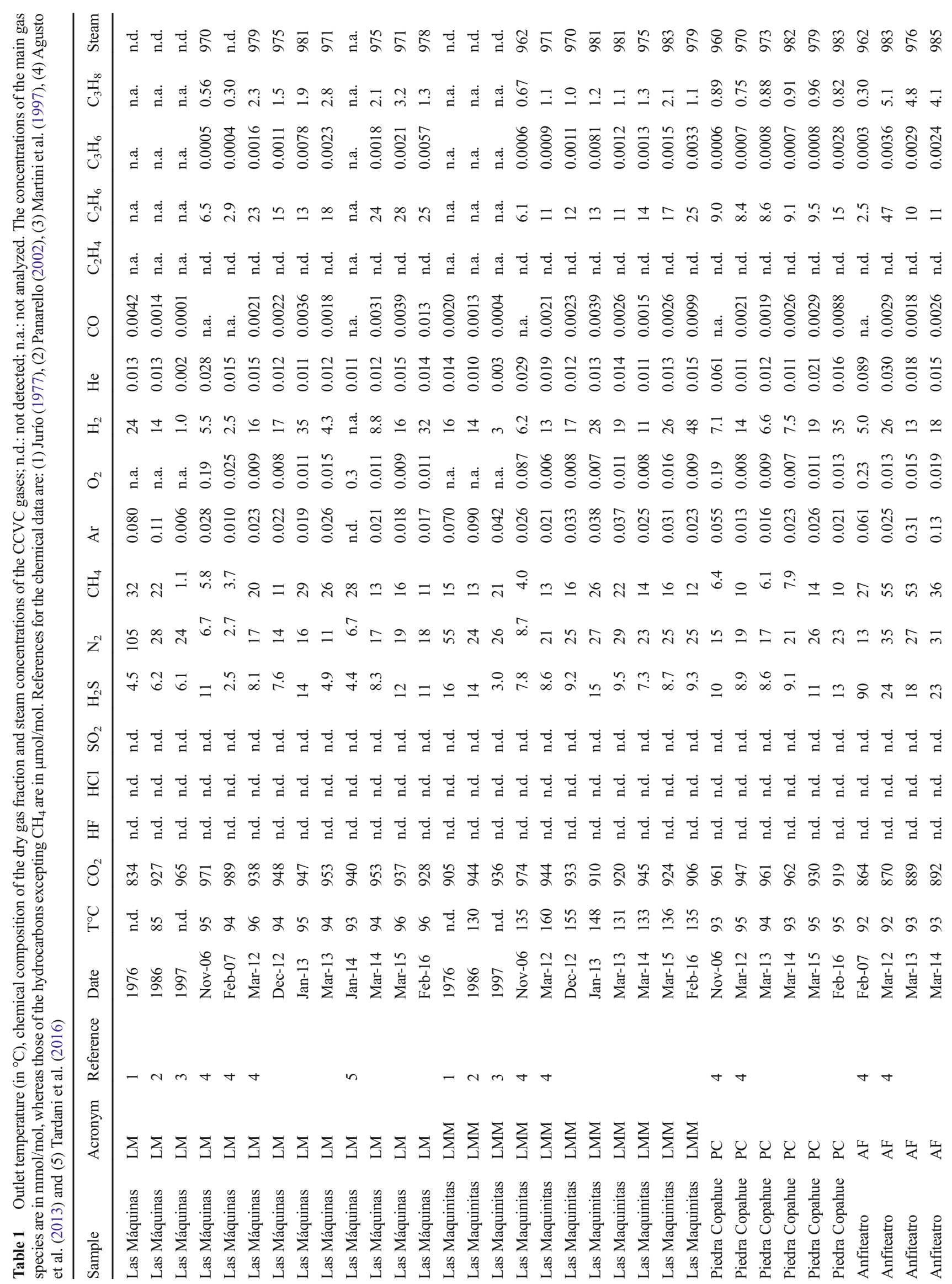


(Capaccioni et al. 2016) and empirical (Tamburello et al. 2015; de Moor et al. 2016b) investigations, as well as theoretical computations (Symonds et al. 2001), have demonstrated that magmatic gas dissolution in liquid water can be negligible at low $\mathrm{pH}$ and relatively high temperature. Hence, the occurrence of significant compositional changes in the hydrothermal emissions of Copahue volcano during the new eruptive cycle which started in 2012 was taken seriously. On the contrary, no clues of the typical magmatic gases $\mathrm{SO}_{2}, \mathrm{HCl}$ and $\mathrm{HF}$ were detected in the investigated distal fumaroles during the whole observation period, whereas these gases were found in significant concentrations in the fluids at the two summit crater fumaroles (Table 1). Therefore, the geothermal aquifers surrounding the volcano efficiently scrubbed these highly soluble gases after the 2012 eruptive activity, despite the fact that the magmatic input at the root of the aquifer was likely increasing (Tassi et al. 2016). The outlet temperatures of most fumaroles were at the boiling point of water at the vent altitude, being likely controlled by the presence of a liquid phase at shallow depth $\left(\sim 90^{\circ} \mathrm{C}\right.$; Table 1$)$. Thus, it is not surprising that they remained constant during the observation period, apart from those at LMM, where a superheated steam $\left(T>100^{\circ} \mathrm{C}\right)$ showed a significant temperature increase $\left(20-25^{\circ} \mathrm{C}\right.$; Table 1$)$ in MarchDecember 2012.

The concentrations of $\mathrm{H}_{2} \mathrm{~S}$ in all the investigated hydrothermal fluid discharges did not follow any specific temporal trend (Fig. 2a). Similarly, $\mathrm{CH}_{4}$ showed wide variations randomly distributed in time (Fig. 2b). The $\mathrm{N}_{2} / \mathrm{Ar}$ ratios oscillated around that measured at the CR1 fumarole, mostly ranging between those of air and a deep component (DC) (Fig. 2c), the latter having an $\mathrm{N}_{2} /$ Ar ratio up to 3500 (Agusto et al. 2013) likely related to sediments derived from the slab rather than continental crust (Tardani et al. 2016). Thus, no evident effects related to the last eruptive phase were shown by the behavior of $\mathrm{H}_{2} \mathrm{~S}, \mathrm{CH}_{4}, \mathrm{~N}_{2}$ and $\mathrm{Ar}$, at least with this sampling frequency. Molecular hydrogen is commonly used as a geo-indicator to estimate temperature and redox conditions regulating the chemistry of hydrothermal fluids, since it reacts rapidly to physical and chemical changes (e.g. Giggenbach 1987). Prior to February 2007, the $\mathrm{H}_{2}$ concentrations were relatively low and constant, whereas in March 2012, a first concentration peak was observed, followed in January 2013 by a second peak, which only occurred at CC, LM and PC. The March 2013 March 2014 period was marked by decreasing trends, whereas a new phase of increase was recorded during the last two years of observation (Fig. 2d). A relationship between the $\mathrm{H}_{2}$ temporal patterns and the main phreatic and phreatomagmatic eruptive events is clearly shown, especially considering that the gas discharges displayed synchronous variations. The January 2013 peak and the sharp increase during the last observation period were also found 
Table $2 \delta^{13} \mathrm{C}_{-} \mathrm{CO}_{2}\left(\%\right.$ vs. V-PDB), $R c / R a,{ }^{4} \mathrm{He} /{ }^{20} \mathrm{Ne}, \delta^{18} \mathrm{O}-\mathrm{H}_{2} \mathrm{O}\left(\% \circ\right.$ vs. V-SMOW) and $\delta \mathrm{D}-\mathrm{H}_{2} \mathrm{O}\left(\% \circ\right.$ vs. V-SMOW) values, and $\mathrm{CO}_{2} /{ }^{3} \mathrm{He}$ of the CCVC gas discharges. References (1)-(5) as in Table 1; (6) Varekamp et al. (2006)

\begin{tabular}{|c|c|c|c|c|c|c|c|c|}
\hline Acronym & Reference & Date & $\delta^{13} \mathrm{C}-\mathrm{CO}_{2}$ & $R c / R a$ & ${ }^{4} \mathrm{He} /{ }^{20} \mathrm{Ne}$ & $\mathrm{CO}_{2}{ }^{3} \mathrm{He}\left(\times 10^{9}\right)$ & $\delta^{18} \mathrm{O}-\mathrm{H}_{2} \mathrm{O}$ & $\delta \mathrm{D}-\mathrm{H}_{2} \mathrm{O}$ \\
\hline LM & 2 & 1986 & & & & & -10.6 & -85 \\
\hline LM & 6 & 2003 & -8.3 & 7.50 & 729 & & & \\
\hline LM & 4 & Nov-06 & -8.2 & 7.72 & 1898 & 3.3 & & \\
\hline LM & 4 & Feb-07 & -8.8 & & & & & \\
\hline LM & 4 & Mar-12 & -7.3 & 7.04 & 1215 & 6.2 & -11.2 & -90 \\
\hline LM & & Dec-12 & -6.9 & 6.67 & 115 & 8.5 & & \\
\hline LM & & Jan-13 & -7.1 & 6.48 & 333 & 9.6 & & \\
\hline LM & & Mar-13 & -7.9 & 6.43 & 485 & 8.9 & -8.6 & -76 \\
\hline LM & 5 & Jan-14 & -8.0 & 7.52 & 68 & 8.2 & & \\
\hline LM & & Mar-14 & -8.6 & 7.60 & 571 & 7.5 & -10.6 & -87 \\
\hline LM & & Mar-15 & -9.6 & 7.65 & 1025 & 5.9 & -10.7 & -90 \\
\hline LM & & Feb-16 & -9.4 & 7.71 & 845 & 6.2 & -10.3 & -92 \\
\hline LMM & 2 & 1986 & & & & & -10.8 & -84 \\
\hline LMM & 4 & Nov-06 & -7.7 & 7.94 & 1679 & 3.1 & & \\
\hline LMM & 4 & Mar-12 & -7.1 & 6.97 & 1330 & 5.2 & -10.8 & -88 \\
\hline LMM & & Mar-13 & -7.8 & 5.89 & 354 & 8.0 & -8.8 & -78 \\
\hline LMM & & Mar-14 & -8.2 & 7.67 & 420 & 8.1 & -10.5 & -90 \\
\hline LMM & & Mar-15 & -8.3 & 7.71 & 644 & 6.7 & -10.8 & -91 \\
\hline LMM & & Feb-16 & -8.1 & 7.68 & 512 & 5.7 & -10.6 & -92 \\
\hline $\mathrm{PC}$ & 6 & 2003 & -8.3 & 7.60 & 1228 & & & \\
\hline $\mathrm{PC}$ & 4 & Nov-06 & -7.7 & 7.36 & 1957 & 1.5 & & \\
\hline PC & 4 & Mar-12 & -7.0 & 7.01 & 1048 & 8.8 & -11.8 & -91 \\
\hline $\mathrm{PC}$ & & Mar-13 & -6.7 & 6.79 & 505 & 8.5 & -8.2 & -80 \\
\hline PC & & Mar-14 & -7.5 & 7.74 & 785 & 8.1 & -9.8 & -88 \\
\hline $\mathrm{PC}$ & & Mar-15 & -8.2 & 7.96 & 1045 & 4.0 & -9.9 & -89 \\
\hline PC & & Feb-16 & -8.7 & 7.94 & 913 & 5.2 & -9.6 & -86 \\
\hline $\mathrm{AF}$ & 4 & Feb-07 & -6.8 & 5.01 & 2445 & 1.4 & & \\
\hline $\mathrm{AF}$ & 4 & Mar-12 & -7.0 & 4.93 & 1996 & 4.3 & -17.9 & -109 \\
\hline $\mathrm{AF}$ & & Mar-13 & -7.6 & 4.63 & 23 & 7.7 & -8.6 & -79 \\
\hline $\mathrm{AF}$ & & Mar-14 & -8.5 & 5.12 & 216 & 8.4 & -8.5 & -80 \\
\hline $\mathrm{AF}$ & & Mar-15 & -8.5 & 5.09 & 254 & 6.8 & -8.7 & -82 \\
\hline $\mathrm{AF}$ & & Feb-16 & -8.8 & 5.16 & 217 & 7.5 & -8.5 & -83 \\
\hline $\mathrm{CC}$ & 4 & Feb-07 & -8.3 & 5.02 & 914 & 3.8 & & \\
\hline $\mathrm{CC}$ & 4 & Mar-12 & -8.1 & 4.04 & 1058 & 8.5 & -8.6 & -89 \\
\hline $\mathrm{CC}$ & & Dec-12 & -7.8 & 4.21 & 144 & 12 & & \\
\hline $\mathrm{CC}$ & & Jan-13 & -8.3 & 4.07 & 84 & 9.0 & & \\
\hline $\mathrm{CC}$ & & Mar-14 & -8.8 & 5.35 & 75 & 9.1 & -8.3 & -78 \\
\hline $\mathrm{CC}$ & & Mar-15 & -9.3 & 5.12 & 217 & 7.5 & -8.2 & -75 \\
\hline $\mathrm{CC}$ & & Feb-16 & -9.2 & 5.22 & 186 & 6.8 & -8.4 & -77 \\
\hline CR1 & & Mar-13 & -9.6 & 7.75 & 458 & 3.0 & -3.5 & -66 \\
\hline $\mathrm{CR} 2$ & & Mar-13 & -9.5 & & & & -3.6 & -70 \\
\hline
\end{tabular}

in the $\mathrm{CO}$ concentrations (Fig. 2e) and the $\mathrm{C}_{3} \mathrm{H}_{6} / \mathrm{C}_{3} \mathrm{H}_{8}$ ratios (Fig. 2f). These data suggest that the magmatic pulses likely causing the volcanic events at Copahue volcano also affected the hydrothermal system, increasing its temperatures and, consequently, enhancing the formation of both
$\mathrm{H}_{2}, \mathrm{CO}$ and $\mathrm{C}_{3} \mathrm{H}_{6}$. The significant temperature increase that affected the hydrothermal reservoir in 2015-2016 is clearly shown in Fig. 3, where the redox independent gas geothermometer proposed by Chiodini and Marini (1998) is reported. 


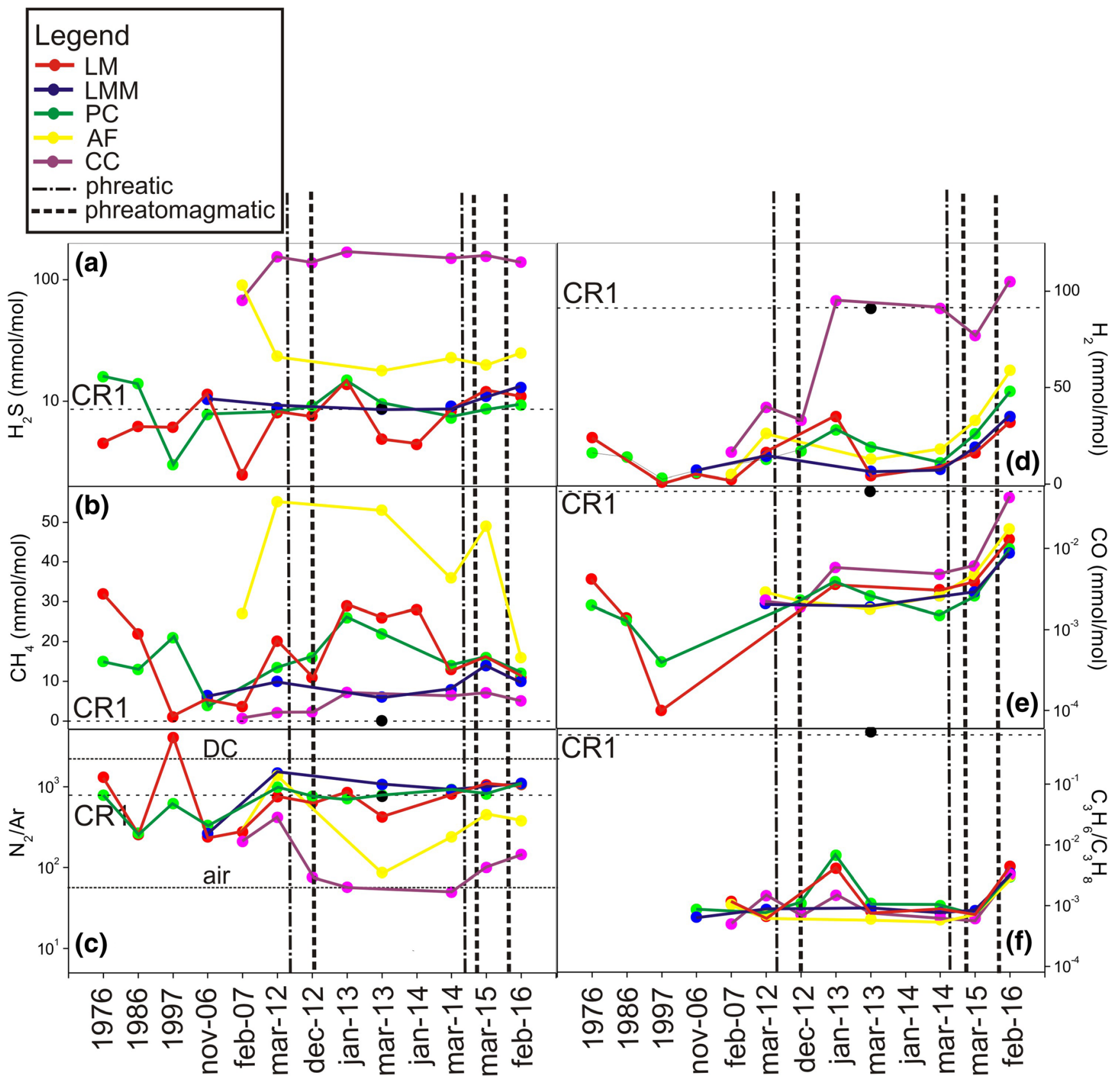

Fig. 2 Time-series of (a) $\mathrm{H}_{2} \mathrm{~S}$, (b) $\mathrm{CH}_{4}$, (c) $\mathrm{N}_{2} / \mathrm{Ar}$, (d) $\mathrm{H}_{2}$, (e) CO, and (f) $\mathrm{C}_{3} \mathrm{H}_{6} / \mathrm{C}_{3} \mathrm{H}_{8}$ from 1976 to February 2016 of gases from the LM (red line), LMM (blue line), PC (green line), AF (yellow line) and CC (magenta line) fluid discharges. The main phreatic (dash-dotted line) and

phreatomagmatic (dash line) eruptions, as well as the CR1 fumarole (black dotted line), are also reported. In (c), the $\mathrm{N}_{2} / \mathrm{Ar}$ ratios of air and a deep component (DC) are also depicted

\section{Temporal evolution of the $\delta^{13} \mathrm{C}-\mathrm{CO}_{2}, R c / R a, \delta^{18} \mathrm{O}-\mathrm{H}_{2} \mathrm{O}$ and $\delta \mathrm{D}-\mathrm{H}_{2} \mathrm{O}$ values}

The Copahue fluids are marked by a high He isotopic ratio (Varekamp et al. 2006; Agusto et al. 2013). It is the highest one measured in the SAVZ (Tardani et al. 2016 and references therein) and fits into the MORB field $(8 \pm 1 R a$; Farley and Neroda 1998; Graham 2002). This peculiar feature is likely related to crustal attenuation and upwelling of mantle asthenosphere caused by the transtensional tectonics that caused the
CCVC pull-apart basin (Folguera et al. 2007). As highlighted by Agusto et al. (2013) and Tassi et al. (2016), the CC and AF gases are characterized by a relatively high degree of crustal contamination, possibly due to shallow fluids permeating through the normal fractures affecting this sector of the volcano (Folguera et al. 2016). In March 2012, i.e. just before the last eruptive cycle, the $R c / R a$ values progressively decreased in all the investigated fluid discharges. In March 2013, the $R c / R a$ values were $1-2$ units lower than those measured in 2003-2007, whereas since March 2014, synchronous 


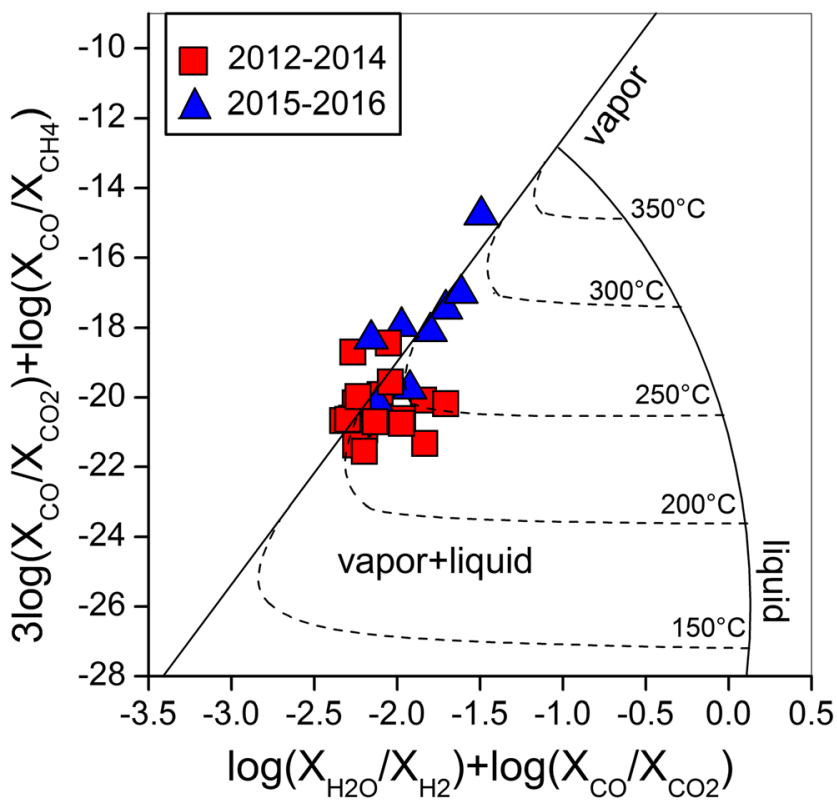

Fig. $3 \log \left[\left(X_{\mathrm{CO}} / X_{\mathrm{CO} 2}\right)-\log \left(X_{\mathrm{H} 2} / X_{\mathrm{H} 2 \mathrm{O}}\right)\right]$ vs. $3 \log \left[\left(X_{\mathrm{CO}} / X_{\mathrm{CO} 2}\right)+\right.$ $\left.\log \left(X_{\mathrm{CO}} / X_{\mathrm{CH} 4}\right)\right]$ binary diagram for the CCVC fumaroles. The theoretical values for a single saturated vapor phase (vapor) and single saturated liquid phase (liquid) are shown. Gases are grouped on the basis of their sampling date: 2012-2014 (red squares); 2015-2016 (blue triangles)

increasing trends have been recorded. In February 2016, the $R c / R a$ values were comparable to, or even higher than, those measured prior to 2012 and those of CR1 (Fig. 4a). The simultaneous variations of the $R c / R a$ values in the studied fumaroles are further evidence for a common deep source of $\mathrm{He}$, notwithstanding the relatively high crustal contamination shown by the gases from $\mathrm{CC}$ and $\mathrm{AF}$ with respect to the other hydrothermal fluid discharges.

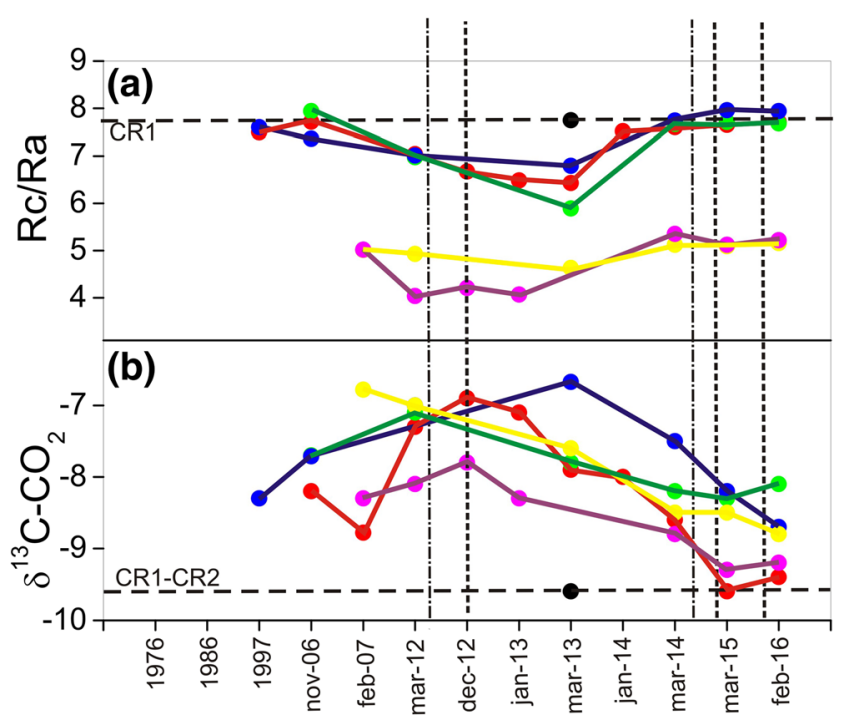

Fig. 4 Time-series of (a) $R c / R a$ and (b) $\delta^{13} \mathrm{C}-\mathrm{CO}_{2}(\% \circ$ vs. V-PDB) from 2003 to February 2016 of gases from the CCVC fumaroles. Symbols as in Fig. 2
Contrasting temporal patterns were given by the $\delta^{13} \mathrm{C}_{-} \mathrm{CO}_{2}$ values, which in 2012 were significantly less negative than those from 2003 to 2007, apart from at AF where the carbon isotope composition in $\mathrm{CO}_{2}$ showed a decreasing trend over the whole observation period (2007-2016). From 2013, the $\delta^{13} \mathrm{C}_{-} \mathrm{CO}_{2}$ values of the $\mathrm{LM}, \mathrm{LMM}$ and $\mathrm{CC}$ discharges also started to decrease, whereas the PC fumarole showed an increasing trend that lasted until March 2013 and then abruptly decreased. The $\delta^{13} \mathrm{C}_{-} \mathrm{CO}_{2}$ values in 2015-2016 were the lowest among those measured for these five fumaroles (Table 2), approaching those of CR1 and CR2 (Fig. 4b).

The $R c / R a$ and $\delta^{13} \mathrm{C}_{-} \mathrm{CO}_{2}$ temporal patterns (Fig. 4a,b) produced two distinct trends in the $\mathrm{CO}_{2} /{ }^{3} \mathrm{He}$ vs. $\delta^{13} \mathrm{C}_{-} \mathrm{CO}_{2}$ binary diagram (Fig. 5): trend $A$, including those gases that were marked by significant $\mathrm{CO}_{2} /{ }^{\beta} \mathrm{He}$ and $\delta^{13} \mathrm{C}-\mathrm{CO}_{2}$ increases in 2006-2013; and trend $B$, delineated by the gases whose $\mathrm{CO}_{2} /{ }^{3} \mathrm{He}$ and $\delta{ }^{13} \mathrm{C}-\mathrm{CO}_{2}$ values, after the period of increase, progressively approached those measured in 2006-2007. An enhanced degassing of the hydrothermal reservoir may theoretically produce an increase in the $\mathrm{CO}_{2}{ }^{\beta} \mathrm{He}$ ratio, due to the higher $\mathrm{CO}_{2}$ solubility in water with respect to that of $\mathrm{He}$ (CRC 2001). If we assume that this process was related to the eruption occurring at the active crater, then the increase in the reservoir temperature, suggested by the behavior of the gas species most sensitive to temperature changes (Fig. 2), is not surprising. However, an increasing rate of gas release from the hydrothermal reservoir would decrease the gas-liquid ${ }^{13} \mathrm{C}-{ }^{12} \mathrm{C}$ fractionation, leading to a decrease in $\delta^{13} \mathrm{C}-\mathrm{CO}_{2}$ values (Deines et al. 1974) towards the CR1-CR2 values, i.e. the opposite of what is observed in 2012-2014 (Fig. 4b). Hence, this process cannot completely explain trend $A$.

As far as trend $B$ is concerned, an increase in magma degassing causes a preferential loss of $\mathrm{CO}_{2}$ with respect to $\mathrm{He}$, the latter having a higher solubility in the melt than the former, thus producing gases characterized by a progressive decrease in both the $\mathrm{CO}_{2}{ }^{\beta} \mathrm{He}$ and $\delta^{13} \mathrm{C}_{-} \mathrm{CO}_{2}$ values (Javoy et al. 1978; Hilton et al. 1998). This would explain, at a first approximation, the changes of these two parameters which occurred after 2014 (Fig. 5). An enhanced contribution of magmatic gases is consistent with the increase in the $R c / R a$ values observed in 2015-2016 (Fig. 4a), but it seems to be in contradiction with the $R c / R a$ decrease observed in 2012 2014, when the last intermittent eruptive cycle, representing the clearest expression of renewed magmatic activity, had already begun. The $R c / R a$ evolution unequivocally indicates that in 2012-2014 the hydrothermal fumaroles received a significant contribution of crustal-type fluids. Overall, the occurrence of an anomalous input of ${ }^{4} \mathrm{He}$ - and ${ }^{13} \mathrm{C}$-rich fluids to the hydrothermal fumaroles in 2012-2014 is the only hypothesis able to reconcile the variations in $R c / R a, \mathrm{CO}_{2} /{ }^{3} \mathrm{He}$ and $\delta^{13} \mathrm{C}$ $\mathrm{CO}_{2}$ values, although it is in apparent contradiction with the evolution of the volcanic activity. Differential SAR Interferometry (DInSAR) measurements showed that, after a 
Fig. $5(\mathbf{a}, \mathbf{b}) \mathrm{CO}_{2} /{ }^{\beta} \mathrm{He}$ vs. $\delta^{13} \mathrm{C}$ $\mathrm{CO}_{2}$ (\%o vs. V-PDB) binary diagram of gases from the $\mathrm{CCVC}$ fumaroles. Panel $\mathbf{b}$ is a zoom of panel a. Gases collected in 2006 2013 (trend $A$ ): red square; gases collected in 2014-2016 (trend $B$ ): blue triangle. The CR1 fumarole (black square) is also reported. Boxes and mixing curves (in panel a) between the three endmembers (organic sediment, limestone and MORB) are from Sano and Marty (1995)

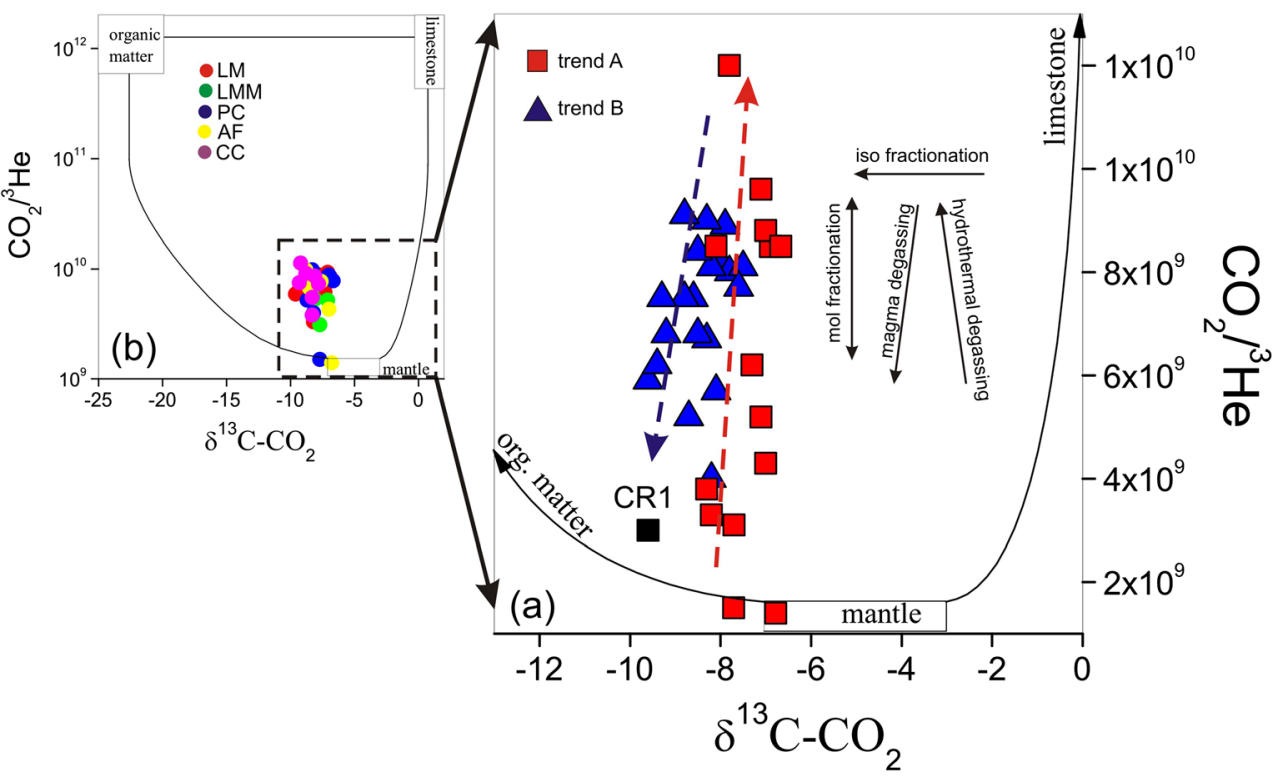

long deflation phase (Velez et al. 2011), Copahue volcano underwent an inflation process from February 2011 to at least January 2013 (no data are available afterward) (Veléz et al. 2016). This inflation, which was interpreted as being related to magma input into the deep (7.5-9 km) chamber that likely promoted the 2012-2016 eruptive cycle, may have caused tensional stress at the surface, favoring the permeation of shallow fluids that affected the chemistry of the uprising hydrothermal gases. The mixing between deep and shallow components, a process that is also responsible for the relatively low $R c / R a$ values characterizing the $\mathrm{CC}$ and $\mathrm{AF}$ fumaroles (Table 2), almost completely masked the increasing heat released from the magmatic system to the root of the hydrothermal reservoir until 2014. The $\mathrm{H}_{2}, \mathrm{CO}$ and $\mathrm{C}_{3} \mathrm{H}_{6} / \mathrm{C}_{3} \mathrm{H}_{8}$ peaks shown in January 2013 by most fumaroles (Fig. 2e-f) were likely caused by the enhanced interaction between the magmatic and hydrothermal fluids. The opposite trends shown by the $R c / R a$ and $\delta^{13} \mathrm{C}_{-} \mathrm{CO}_{2}$ values in 2012-2013 (Fig. 4a,b, respectively) may have an alternative explanation. Under the stress related to the intense seismic activity that occurred prior to the 2012 eruptive events, crustal $\left({ }^{4} \mathrm{He}\right.$ - and ${ }^{13} \mathrm{C}$-rich) fluids may have been released, a process that is commonly considered as being precursory to earthquakes (Khilyuk et al. 2000). Strong variations in He isotopes associated with seismic crisis have also been described by other authors (e.g. Padron et al. 2013). The inversion of the $R c / R a$ and $\delta{ }^{13} \mathrm{C}_{-}-\mathrm{CO}_{2}$ trends which occurred in 2013 (Fig. 4a,b) indicates that the crustal gas contribution (from permeation of shallow fluids and/or gases released from crustal rocks) started to decrease, allowing the progressive increase of the magmatic gas fraction. Accordingly, the $R c / R a, \mathrm{CO}_{2}{ }^{\beta} \mathrm{He}$ and $\delta^{13} \mathrm{C}_{-} \mathrm{CO}_{2}$ values characterizing the hydrothermal discharges in 2006-2007, as well as the CR1 fumarole, were almost completely restored in 2015-2016. Further evidence for this process is the remarkable increase in $\mathrm{H}_{2}$ and $\mathrm{CO}$ concentrations (Fig. 2e,d) and $\mathrm{C} 3 \mathrm{H} 6 / \mathrm{C} 3 \mathrm{H} 8$ ratios (Fig. 2f). It is worth noting that CR1 showed a $\delta^{13} \mathrm{C}_{-}-\mathrm{CO}_{2}$ value which was more negative than the lower limit of the range of values for both MORB and high-temperature volcanic gases $(-6.5 \pm 2.2$ and $-5.5 \pm 2.2 \%$ vs. V-PDB, respectively; e.g. Sano and Marty 1995; Sano and Williams 1996), and $\mathrm{CO}_{2}{ }^{3} \mathrm{He}$ ratio lower than that related to global arc-like values $(1.5 \pm 1.1 \times 1010$; e.g. Sano and Williams 1996). Hence, assuming that the chemical features of this high-temperature fumarole (sampled in March 2013) approached those of the magmatic fluids, the latter seem to have suffered a certain degree of $\mathrm{CO}_{2}-\mathrm{He}$ and ${ }^{13} \mathrm{C}-{ }^{12} \mathrm{C}$ fractionation processes, which were likely produced by the enhanced magma degassing related to the 2012 eruptive events. Evidences of magmatic fluids in the hydrothermal discharges were also traced by the $\delta^{18} \mathrm{O}-\mathrm{H}_{2} \mathrm{O}$ and $\delta \mathrm{D}-\mathrm{H}_{2} \mathrm{O}$ values. When only those of the March 2012 samples were considered, they provided an indication of ${ }^{18} \mathrm{O}$ enrichment caused by water-rock interaction processes (Fig. 6; Agusto et al. 2013). On the contrary, according to the new complete dataset, a convergence with the CR1 and CR2 samples was shown (Fig. 6), suggesting a significant contribution of andesitic water (Taran et al. 1989; Giggenbach 1992).

\section{Conclusions}

The geochemical monitoring carried out over the last 40 years at Copahue volcano, although discontinuous, has provided useful insights into the mechanisms regulating the chemical 


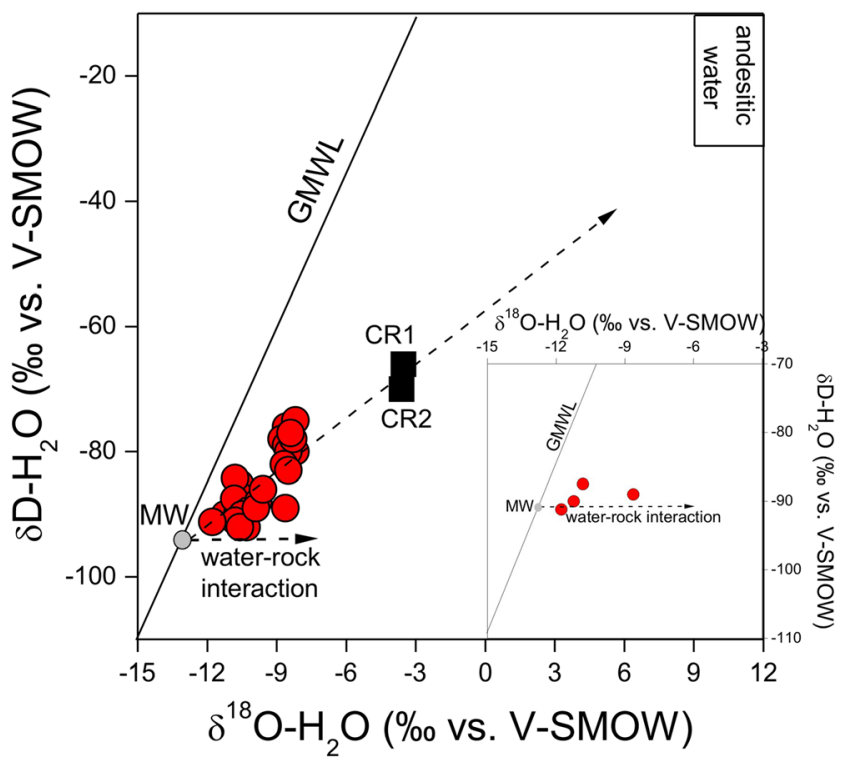

Fig. $6 \delta^{18} \mathrm{O}-\mathrm{H}_{2} \mathrm{O}\left(\% \circ\right.$ vs. V-SMOW) vs. $\delta \mathrm{D}-\mathrm{H}_{2} \mathrm{O}(\% \circ$ vs. V-SMOW) binary diagram of gases from the CCVC fumaroles. In the inset, the binary diagram is reported at different $x$ and $y$ scales. The isotopic compositions of local meteoric water (MW), the Global Meteoric Water Line (GMWL; Craig 1961) and the "andesitic" water field (Taran et al. 1989; Giggenbach 1992) are also reported. Hydrothermal fumaroles: red circle; active crater fumarole: black square

and isotopic changes that affected the hydrothermal fluid discharges during the 2012-2016 eruptive cycle. The $\mathrm{H}_{2}$ and $\mathrm{CO}$ concentrations, as well as the ratio between the $\mathrm{C}_{3}$ alkenealkane pair, showed occasional peaks (in March 2012, January 2013 and in 2015-2016; Fig. 2), indicating episodes of disturbance of the fumarolic fluids in correspondence with the main volcanic events that occurred at the active crater. The behavior of these geochemical parameters revealed that the enhanced input of hot magmatic fluids at the root of the hydrothermal reservoir related to the volcanic activity produced, albeit with a time delay, a detectable signal at the surface. On the contrary, the temporal evolution of the $\delta^{13} \mathrm{C}-\mathrm{CO}_{2}, R c / R a$ and $\mathrm{CO}_{2} /{ }^{3} \mathrm{He}$ values in 2006-2014 was unexpected, since they clearly indicated a significant decrease in the magmatic fluid contribution over a period in which several eruptions occurred. The two most reliable hypotheses for this behavior are based on (a) the effect of the inflation process, affecting the volcano since early 2011 , on ground permeability that favored the mixing between the uprising hydrothermal fluids and a shallow ${ }^{13} \mathrm{C}$-rich and ${ }^{3} \mathrm{He}$-poor end-member and (b) an enhanced release of gases from crustal rocks associated with the earthquakes that occurred prior to the 2012 eruptive activity. Only since 2013 have the $\delta^{13} \mathrm{C}_{-} \mathrm{CO}_{2}$ and $R c / R a$ values evolved towards a progressive increase in the magmatic component.

Overall, the interpretation of this large time-series of geochemical data highlighted that the hydrothermal fluids discharged from the peripheral vents did not show any precursory signals of the new incoming eruptive phase; heat and magmatic gases were efficiently buffered by the hydrothermal reservoir. Hence, the compositional changes of the fluids discharged at the surface were smoothed and delayed. Moreover, a frequent (e.g. monthly) sampling of these gases is difficult due to the adverse meteorological conditions that characterize the area for most part of the year. To forecast rejuvenation of volcanic activity, which in this volcano typically occurs at the active crater (Caselli et al. 2016b), the installation of a geophysical array (Caselli et al. 2016c and references therein) combined with ground deformation measurements from satellites (Veléz et al. 2016), as well as geochemical monitoring of the stream (namely Rio Agrio) fed by the hot and hyperacidic springs located close to the rim of the active crater (Agusto and Varekamp 2016), seems the most appropriate approach. A MultiGAS instrument could be placed at the summit crater rim to provide medium-to-longterm (on the scale of months) data series of selected geochemical parameters (e.g. $\mathrm{CO}_{2} / \mathrm{Ar}, \mathrm{H}_{2} / \mathrm{Ar}$ ), possibly able to detect changes in the volcanic gas emission rate from the central degassing system even during quiescent periods. On the other hand, the relative stability of this hydrothermal system, persisting even during a volcanic crisis, represents a fundamental advantage for geothermal exploitation, which may cause renewed interest in this resource following the first promising attempts carried out over the past few decades. However, the increase in $\mathrm{H}_{2}$ and $\mathrm{CO}$ concentrations and that of the $\mathrm{C}_{3} \mathrm{H}_{6} / \mathrm{C}_{3} \mathrm{H}_{8}$ ratio observed after March 2015 deserves particular attention. A new period of unrest at Copahue volcano followed by new volcanic events may indeed significantly modify the geochemical composition of the peripheral gas emissions since in this case the presence of magmatic fluids in these discharges cannot be completely ruled out. Consequently, periodic geochemical monitoring should be performed independent of further developments of geothermal projects.

Acknowledgement Enrico Calvi (CNR-IGG) and Enrico Maria Selmo (University of Parma) are gratefully acknowledged for their help during the isotopic measurements of carbon in $\mathrm{CO}_{2}$ and oxygen and hydrogen, respectively. The authors also thank Dr. Andrea Rizzo and M. Tantillo for the analysis of $\mathrm{He}$ isotopes carried out at the INGV laboratories of Palermo (Italy). The authors wish to thank M. de Moore, A. Harris and an anonymous reviewer for their helpful comments and suggestions. This work was carried out in the framework of a general agreement between the University of General Roca (Argentina) and the University of Florence (Italy).

\section{References}

Agusto M, Varekamp J (2016) The Copahue hydrothermal system and applications for volcanic surveillance. In: Tassi F, Vaselli O, Caselli A (eds) Copahue, active volcanoes of the world. Springer VerlagBerlin, Heidelberg, pp 199-238 
Agusto M, Tassi F, Caselli AT, Vaselli O, Rouwet D, Capaccioni B, Caliro S, Chiodini G, Darrah T (2013) Gas geochemistry of the magmatichydrothermal fluid reservoir in the Copahue-Caviahue Volcanic Complex (Argentina). J Volcanol Geotherm Res 257:44-56

Aiuppa A, Federico C, Guiudice G, Guiuffrida G, Guida R, Gurrieri S, Liuzzo M, Moretti R, Papa P (2009) The 2007 eruption of Stromboli volcano: insights from real-time measurement of the volcanic gas plume $\mathrm{CO}_{2} / \mathrm{SO}_{2}$ ratio. J Volcanol Geotherm Res 182:221-230

Capaccioni B, Tassi F, Vaselli D, Tedesco D, Rossi PML (2005) The November 2002 degassing event at Panarea Island (Italy): the results of a 5 months geochemical monitoring program. Ann Geophys 48: 755-765

Capaccioni B, Tassi F, Vaselli O, Tedesco D, Poreda R (2007) Submarine gas burst at Panarea Island (southern Italy) on 3 November 2002: a magmatic versus hydrothermal episode. J Geophys Res 112:B05201

Capaccioni B, Rouwet D, Tassi F (2016) Cl degassing from extremely acidic crater lakes: preliminary results from experimental determinations and implications for geochemical monitoring. In: Obha $\mathrm{T}$, Capaccioni B, Caudron C (eds) Geol Soc London Special Publ 437. https://doi.org/10.1144/SP437.12

Caselli AT, Agusto M, Velez ML, Forte P, Bengoa C, Capaccioni B (2016a) The 2012 eruption. In: Tassi F, Vaselli O, Caselli A (eds) Copahue, active volcanoes of the world. Springer Verlag-Berlin, Heidelberg, pp 61-77

Caselli AT, Liccioli C, Tassi F (2016b) Risk assessment and mitigation at Copahue volcano. In: Tassi F, Vaselli O, Caselli A (eds) Copahue, active volcanoes of the world. Springer Verlag-Berlin, Heidelberg, pp 239-254

Caselli AT, Velèz ML, Agusto M, Liccioli C, Vaselli O (2016c) Prehistoric to historic volcanic activity at Copahue volcano. In: Tassi F, Vaselli O, Caselli A (eds) Copahue, active volcanoes of the world. Springer Verlag-Berlin, Heidelberg, pp 49-59

Cembrano J, Hervé F, Lavenu A (1996) The Liquiñe Ofqui fault zone: a long-lived intra-arc fault system in southern Chile. Tectonophysics 259:55-66

Cembrano J, Lavenu A, Reynolds P, Arancibia G, López G, Sanhueza A (2002) Late Cenozoic transpressional ductile deformation north of the Nazca-South America-Antarctica triple junction. Tectonophysics 354:289-314

Chiodini G, Marini L (1998) Hydrothermal gas equilibria: the $\mathrm{H}_{2} \mathrm{O}-\mathrm{H}_{2}-$ $\mathrm{CO}_{2}-\mathrm{CO}-\mathrm{CH}_{4}$ system. Geochim Cosmochim Acta 62(15):26732687

Chiodini G, Cioni R, Marini L, Panichi C (1995) Origin of the fumarolic fluids of Vulcano Island, Italy and implications for volcanic surveillance. Bull Volcanol 57:99-110

Craig H (1961) Isotopic variations in meteoric waters. Science 133:17021703

CRC (2001) In: Lide DR (ed) Handbook of chemistry and physics, 82nd edn. CRC Press, Boca Raton LLC

de Moor JM, Aiuppa A, Avard G, Wehrmann H, Dunbar N, Muller C, Tamburello G, Giudice G, Liuzzo M, Moretti R, Conde V, Galle B (2016a) Turmoil at Turrialba Volcano (Costa Rica): degassing and eruptive processes inferred from high-frequency gas monitoring. J Geophys Res Solid Earth 121:5761-5775

de Moor JM, Aiuppa A, Pacheco J, Avard G, Kern C, Liuzzo M, Martinez M, Giudice G, Fischer TP (2016b) Short period volcanic gas precursors to phreatic eruptions: insights from Poás Volcano. Costa Rica. Earth Planet Sci Lett 442:218-227

Deines P, Langmuir D, Herman RS (1974) Stable carbon isotope ratio and the existence of a gas phase in the evolution of carbonate groundwaters. Geochim Comoschim Acta 38:1147-1164

Evans W, White L, Rapp J (1998) Geochemistry of some gases in hydrothermal fluids from the southern Juan de Fuca Ridge. J Geophys Res 15:305-313

Farley KA, Neroda E (1998) Noble gases in the Earth's mantle. Annu Rev Earth Planet Sci 26:189-218
Fischer TP, Arehart GB, Sturchio NC, Williams SN (1996) The relationship between fumarole gas composition and eruptive activity at Galeras Volcano (Colombia). Geology 24:531-534

Fischer TP, Hilton DR, Zimmer MM, Shaw AM, Sharp ZD, Walker JA (2002) Subduction and recycling of nitrogen along the Central American margin. Science 297:1154-1157

Fischer TP, Ramìrez C, Mora-Amador RA, Hilton DR, Barnes JD, Sharp ZD, Le Brun M, de Moor JR, Barry PH, Füry E, Shaw AM (2015) Temporal variations in fumarole gas chemistry at Poás volcano, Costa Rica. J Volcanol Geotherm Res 294:56-70

Folguera A, Introcaso A, Giménez M, Ruiz F, Martinez P, Tunstall C, García Morabito E, Ramos VA (2007) Crustal attenuation in the Southern Andean retroarc ( $\left.38^{\circ}-39^{\circ} 30^{\prime} \mathrm{S}\right)$ determined from tectonic and gravimetric studies: the Lonco-Luán asthenospheric anomaly. Tectonophysics 239:129-147

Folguera A, Rojas Vera E, Vélez L, Tobal J, Orts D, Agusto M, Caselli A, Ramos VA (2016) A review of the geology, structural controls, and tectonic setting of Copahue volcano, Southern Volcanic Zone, Andes, Argentina. In: Tassi F, Vaselli O, Caselli A (eds) Copahue, active volcanoes of the world. Springer Verlag-Berlin, Heidelberg, pp 3-22

Forte P, Bengoa C, Caselli A (2012) Análisis preliminar de la actividad sísmica del complejo volcánico Copahue-Caviahue mediante técnicas de array. Proceed. XIII Congreso Geológico Chileno, Antofagasta, pp 574-576

Giggenbach WF (1987) Redox processes governing the chemistry of fumarolic gas discharges from White Island, New Zealand. Appl Geochem 2:143-161

Giggenbach WF (1992) Isotopic shifts in waters from geothermal and volcanic systems along convergent plate boundaries and their origin. Earth Planet Sci Lett 113:495-510

Giggenbach WF (1996) Chemical composition of volcanic gases. In: Scarpa R, Tilling R (eds) Monitoring and mitigation of volcano hazard. Springer-Verlag, Berlin, pp 222-256

Giggenbach WF, Sano Y, Wakita H (1993) Isotopic composition of helium, and $\mathrm{CO}_{2}$ and $\mathrm{CH}_{4}$ contents in gases produced along the New Zealand part of a convergent plate boundary. Geochim Cosmochim Acta 57:3427-3455

Graham DW (2002) Noble gas isotope geochemistry of mid-ocean ridge and ocean island basalts: characterization of mantle source reservoirs. Rev Mineral Geochem 47:247-318

Hilton DR, McMurtry GM, Goff F (1998) Large variations in vent fluid $\mathrm{CO}_{2}{ }^{\beta} \mathrm{He}$ ratios signal rapid changes in magma chemistry at Loihi Seamount, Hawaii. Nature 396:359-362

Hilton DR, Fischer TP, Marty B (2002) Noble gases in subduction zones and volatile recycling. In: Porcelli D, Ballentine C, Wieler R (eds) Noble gas in Geochemistry and Cosmochemistry. Mineral Soc Am Spec 47:319-370

Hilton DR, Ramirez CJ, Mora-Amador R, Fischer TP, Füri E, Barry PH, Shaw AM (2010) Monitoring of temporal and spatial variations in fumarole helium and carbon dioxide characteristics at Poàs and Turrialba volcanoes, Costa Rica (2001-2009). Geochem J 44:431440

Javoy M, Pineau F, Iiyama I (1978) Experimental determination of the isotopic fractionation between gaseous $\mathrm{CO}_{2}$ and carbon dissolved in tholeiitic magma; a preliminary study. Contrib Mineral Petrol 67: 35-39

JICA (Japan International Cooperation Agency) (1992) The feasibility study on the Northern Neuquén Geothermal Development Project. Ente Provincial de Energia de la Provincial del Neuquén, pp 89 (in Spanish)

Jurío RL (1977) Características geoquímicas de los fluidos termales de Copahue (Neuquén, Argentina). Principales implicancias geotérmicas. Minería 172:1-11 (in Spanish) 
Khilyuk LF, John O, Robertson JO Jr, Endres B, Chilingarian GV (2000) Gas migration: events preceding earthquakes, 1st edn. Gulf Professional Publishing, Houston, p 400

Mamyrin B, Tolstikhin I (1984) Helium isotopes in nature. In: Fyfe W (ed) Development in geochemistry. Elsevier, Amsterdam, p 288

Martini M, Bermudez A, Delpino D, Giannini L (1997) The thermal manifestations of Copahue volcano area. Neuquen, Argentina. Proceed. VIII Congreso Geologico Chileno, Antofagasta, Chile, 1: 352-356

Mas LC, Mas GR (2016) Geothermal energy development at Copahue volcano. In: Tassi F, Vaselli O, Caselli A (eds) Copahue, active volcanoes of the world. Springer Verlag-Berlin, Heidelberg, pp 257-271

Melián G, Tassi F, Pérez N, Hernández P, Sortino F, Vaselli O, Padrón E, Nolasco D, Barrancos J, Padilla G, Rodríguez F, Dionis S, Calvo D, Notsu K, Sumino H (2012) A magmatic source for fumaroles and diffuse degassing from the summit crater of Teide Volcano (Tenerife, Canary Islands): a geochemical evidence for the 2004-2005 seismic-volcanic crisis. Bull Vulcanol 74:1465-1483

Melnick D, Folguera A, Ramos V (2006) Structural control on arc volcanism: the Caviahue-Copahue complex, central to Patagonian Andes transition $\left(38^{\circ} \mathrm{S}\right)$. J S Am Earth Sci 22:66-88

Menyailov IA, Nikitina LP, Shapar VN, Pilipenko VP (1986) Temperature increase and chemical change of fumarolic gases at Momotombo Volcano, Nicaragua, in 1982-1985; are these indicators of a possible eruption? J Geophys Res B 91(12):12199-112214

Montegrossi G, Tassi F, Vaselli O, Buccianti A, Garofalo K (2001) Sulfur species in volcanic gases. Anal Chem 73:3709-3715

Ozima M, Posodek FA (1983) Noble gas geochemistry. Cambridge University Press, Cambridge

Padron E, Perez NM, Hernandez PA, Sumino H, Melian G, Barrancos J, Nolasco D, Padilla G, Dionis S, Rodriguez F, Hernandez I, Calco D, Peraza MD, Nagao K (2013) Diffusive helium emissions as a precursory sign of volcanic unrest. Geology 41:539-542

Panarello HO (2002) Características isotópicas y termodinámicas de reservorio del campo geotérmico Copahue-Caviahue, provincia del Neuquén. Rev Asoc Geol Argent 57(2):182-194

Panarello HO, Levin M, Albero MC, Sierra JL, Gingins MO (1988) Isotopic and geochemical study of the vapour dominated geothermal field of Copahue (Neuquén, Argentina). Rev Bras Geofís 5(2):275282

Pesicek J, Engdahl E, Thurber C, DeShon H, Lange D (2012) Mantle subducting slab structure in the region of the 2010 M8.8 Maule earthquake (30-40 $\left.{ }^{\circ} \mathrm{S}\right)$, Chile. Geophys J Int 191:317-324

Petrinovic IA, Villarosa G, Délia L, Guzmán SP, Páez GN, Oues V, Manzoni C, Delménico A, Balbis C, Carniel R, Hernando IR (2014) La erupción del 22 de diciembre de 2012 del volcán Copahue, Neuquén, Argentina: caracterización del ciclo eruptivo y sus productos. Rev Asoc Geol Argent 71:161-173

Poreda RJ, Craig H (1989) Helium isotope ratios in circum-Pacific volcanic arcs. Nature 338:473-478

Radic J (2010) Las cuencas cenozoicas y su control en el volcanismo de los complejos Nevados de Chillán y Copahue-Callaqui $\left(36^{\circ}-39^{\circ} \mathrm{S}\right)$. Andean Geol 37(1):220-246

Rizzo A, Barberi F, Carapezza ML, Di Piazza A, Francalanci L, Sortino F, D'Alessandro W (2015) New mafic magma refilling a quiescent volcano: evidence from $\mathrm{He}-\mathrm{Ne}-\mathrm{Ar}$ isotopes during the 2011-2012 unrest at Santorini, Greece. Geochem Geophys Geosyst 16(3):798814

Sano Y, Fischer TP (2013) The analysis and interpretation of noble gases in modern hydrothermal systems. In: Burnard P (ed) Noble gases as geochemical tracers. Series: advances in isotope geochemistry. Springer Verlag, Heidelberg, pp 249-317
Sano Y, Marty B (1995) Origin of carbon in fumarolic gas from island arcs. Chem Geol 119:265-274

Sano Y, Williams SN (1996) Fluxes of mantle and subducted carbon along convergent plate boundaries. Geophys Res Lett 23:2749 2752

Shaw AM, Hilton DR, Fischer TP, Walker JA, Alvarado G (2003) Contrasting He-C relationships in Nicaragua and Costa Rica: insights into $\mathrm{C}$ cycling through subduction zones. Earth Planet Sci Lett 214:499-513

Stern CR (2004) Active Andean volcanism: its geologic and tectonic setting. Rev Geol Chile 31(2):161-206

Stoibert J, Rose W (1970) The geochemistry of Central-American volcanic gas condensates. Geol Soc Am Bull 81:2891-2912

Symonds RB, Mizutani Y, Briggs PH (1996) Long-term geochemical surveillance of fumaroles at Showa-Shinzan dome, Usu volcano, Japan. J Volcanol Geotherm Res 73:177-211

Symonds RB, Gerlach TM, Reed MH (2001) Magmatic gas scrubbing: implications for volcano monitoring. J Volcanol Geotherm Res 108: 303-341

Tamburello G, Agusto M, Caselli A, Tassi F, Vaselli O, Calabrese S, Rouwet D, Capaccioni B, Di Napoli R, Cardellini C, Chiodini G, Bitetto M, Brusca L, Bellomo S, Aiuppa A (2015) Intense magmatic degassing through the lake of Copahue volcano, 2013-2014. J Geophys Res Solid Earth 120. https://doi.org/10.1002/ 2015JB012160

Taran YA, Pokrovsky BG, Esikov AD (1989) Deuterium and oxygen18 in fumarolic steam and amphiboles from some Kamchatka volcanoes: 'andesitic waters'. Dokl Akad Nauk SSSR 304:440443

Tardani D, Reich M, Roulleau E, Takahata N, Sano Y, Péres-Flores P, Sànchez-Alfaro P, Cembrano J, Arancibia G (2016) Exploring the structural controls on helium, nitrogen and carbon isotopes signatures in hydrothermal fluids along an intra-arc fault system. Geochim Cosmochim Acta 184:193-211

Tassi F, Vaselli O, Barbosa V, Fernandez E, Duarte E (2004) Fluid geochemistry and seismic activity in the period 1998-2002 at Turrialba Volcano (Costa Rica). Ann Geophys 47(4):1-11

Tassi F, Agusto M, Vaselli O, Chiodini G (2016) Geochemistry of the magmatic-hydrothermal fluid reservoir of Copahue volcano (Argentina): insights from the chemical and isotopic features of fumarolic discharges. In: Tassi F, Vaselli O, Caselli A (eds) Copahue, active volcanoes of the world. Springer Verlag-Berlin, Heidelberg, pp 119-139

Varekamp JC, Ouimette AP, Kreulen R (2004) The magmatohydrothermal system of Copahue Volcano, Argentina. In: Wanty RB, Seal RB II (eds) Water-rock interaction, 11. Bakema Publishers, Leiden, pp 215-218

Varekamp JC, Maarten de Moor J, Merrill M, Colvin A, Goss A, Vroon P, Hilton D (2006) Geochemistry and isotopic characteristics of Caviahue-Copahue volcanic complex, province of Neuquen, Argentina. In: Kay S, Ramos A (eds) Evolution of an Andean margin: a tectonic and magmatic view from the Andes to the Neuquen Basin (35 $-39^{\circ} \mathrm{S}$ lat). Geol Soc Am Spec Issue 407:317-342

Vaselli O, Tassi F, Duarte E, Fernandez E, Poreda R, Delgado Huertas A (2010) Evolution of fluid geochemistry at the Turrialba volcano (Costa Rica) from 1998 to 2008. Bull Vulcanol 72(4):397-410

Velez ML, Euillades P, Caselli A, Blanco M, Martínez Díaz J (2011) Deformation of Copahue volcano: inversion of InSAR data using a genetic algorithm. J Volcanol Geotherm Res 202(1-2):117-126

Veléz ML, Euillades P, Blanco M, Euillades L (2016) Ground deformation between 2002 and 2013 from InSAR observations. In: Tassi F, Vaselli O, Caselli A (eds) Copahue, active volcanoes of the world. Springer Verlag-Berlin, Heidelberg, pp 185-198 